\title{
Statistical Model Representing Workers Turnover Problem in Third Developing Countries: Jordanian Industrial Sector
}

\author{
Wisam M. Abu Jadayil \\ Department of Mechanical and Industrial Engineering \\ The University of Ras Al Khaimah, UAE 10021 \\ Email: Wisam.abujadayil@aurak.ae \\ Mousa S. Mohsen \\ Department of Mechanical and Industrial Engineering \\ The University of Ras Al Khaimah, UAE 10021 \\ Email: mousa.mohsen@aurak.ae \\ Adnan Al-Bashir \\ Department of Industrial Engineering \\ The Hashemite University, Jordan 13135 \\ Email: Adnanbashir99@yahoo.com
}

Accepted: Feb 16, 2013 Published: March 03, 2013

Doi:10.5296/ijhrs.v3i4.4482 URL: http://dx.doi.org/10.5296/ijhrs.v3i4.4482

\begin{abstract}
Jordan as one example of Middle Eastern countries suffers from the problem of workers turnover. This paper analyzed this issue numerically and by building a statistical model to find out the main reasons causing this problem as a first step towards the right solution. Five main categories for workers turnover were studied and investigated. The salary, the working environment, the helpfulness and corporation of the management, the worker psychological state and relationships with surrounding environment, and the services provided by the employer to the employee. Statistical analysis of the results showed that the main reason for turnover in industrial cities is the salary.
\end{abstract}

Key Words: Workers Turnover, Jordanian Industrial Sector, Salary, Working Conditions.

\section{INTRODUCTION}

Understanding workers flow is the fundamental aspect for understanding the market and how successful the economy of the country is. Although it is known that workers flow is very large in Jordan, the basic reasons which cause this workers turnover is not well realized yet. No comprehensive studies in the literature have been made until now, neither 
in Jordan nor in the Middle East region, to investigate those reasons. Instability in economy might lead to workers turnover as a result for looking for more satisfaction, higher wages and better working conditions.

The main reason for workers turnover might be different from country to another and from culture to another. So, Jordan, as a country in the Middle East, might have its reasons for large workers flow which does really deserve to be studied and investigated.

\section{LITERATURE REVIEW}

Many research studies have been made for investigating the main reasons for workers turnover all over the world. Lane et. al. [1] studied in 1996 workers and job flows. They found a great deal of variation in both worker and job flows by sector: they also found that job flows are not synonymous with worker flows. Hassink [2] studied in 1996 the rate of job turnover in which the internal mobility of workers is involved is higher in large firms than in small firms. He found that large firms are able to reduce turnover costs by using their ability to attain a higher internal mobility rate. Lee and Maurer [3] stated in their article in 1997 the initial steps toward understanding how to retain knowledge workers, with a particular focus on engineers. In their conclusion, they suggested that to offer a menu of possible interventions that the manager might consider for more specific conditions. In 1998 Bartol and Martin [4] found that two forms of applicant market-referent information, number of applications filed and degree of target organization wage information possessed, were both significantly and positively related to turnover. Lucifora [5] stated in 1998 that empirical evidence suggests that Italian trade unions have succeeded in reducing turnover. Lehmann and Wadsworth [6] showed in 2000 that tenure-turnover rates are higher in Russia and lower in Poland than in Britain. Strand [7] in 2000 showed that inefficiencies due to bargaining and externalities in the matching process lead firms to employ too few worker types. Lambert et. al. [8] study in 2001 found that indicate that the work environment is more important in shaping worker job satisfaction than are demographic characteristics, and that job satisfaction is a highly salient antecedent of turnover intent. In 2002 Gautier et. al. [9] investigated whether employers exploit cyclical downturns to improve the average skill level of their work force. Their findings are that at each job level mainly lower educated workers leave during downturns. They found no evidence that higher educated workers crowd out lower educated workers during recessions. Haltiwanger and Vodopivec [10] studied in 2002 the labor market flows of one of the rapid reformers among the transition economies; Estonia, and found that the surge in labor market flows in Estonia contrasts sharply with the experience of other transition economies that pursued more gradual reforms.

In 2003 Maertz et. al [11] developed a turnover model that is exclusively valid in Anglo cultures. Same year Alfaro and Tribo [12] discussed the turnover of operations managers and the effect of that on the fluctuations of the inventory. In 2004 Bauer and Bender [13] used a German employer-employee matched panel data set to investigate the effect of organizational and technological changes on gross job and worker flows. The empirical results indicate that organizational change is skill-biased because it first and foremost reduces net employment growth rates of unskilled and medium-skilled workers via higher job destruction and separation rates, whereas the employment patterns of skilled workers are not affected significantly. 
Munasinghe and Sigman [14] presented in 2004 an analysis of labor mobility as a predictor of wages and job turnover. They showed that whether stayers earn more than movers depend on the distribution of outside wage offers and firm-specific wage growth rate. In 2005, Tsou and Liu [15] found a negative relationship between wage dispersion and job reallocation, and (excess) worker turnover in Taiwan. On the other hand DaleOlsen [16] in 2006 found a positive correlation between wages and fringe benefits in Norway. He concluded that higher wages and more fringe benefits reduce the worker turnover rate. Same year Liu [17] studied again the turnover in Taiwan and found that hiring determines worker entry and quits most strongly contribute to worker exit. Munasinghe [18] found that workers with favorable job assessments have a lower and flatter tenure-turnover profile. Morrison et. al. [19] found that in New Zealand the quitting behaviour of workers is a function of local labour market conditions, non-wage income and the costs and benefits of migration to other local labour markets. Sousa-Poza and Sousa-Poza [20] studied the effect of job satisfaction on labor turnover by gender in Switzerland. Their results confirm that job satisfaction is a very good predictor of future quits and here is no apparent difference in firm attachment between men and women. In 2007 Senter and Martin [21] studied the factors affecting the turnover of different groups of part time workers, and concluded that organizational commitment, job satisfaction, and perceived employment alternatives differentially predict turnover for these part-time groups.

Wheeler [22] provided in 2008 an explanation for the observed positive association between average producer size and the magnitude of an industry's presence within local labor markets. Turnover factors revisited and a longitudinal study of Taiwan-based staff nurses was made in 2008 by Chen et. al. [23]. Their study confirms earlier findings on the relationships among turnover determinants, job satisfaction, and intent to stay, and suggests a more comprehensive selection of turnover factors must be taken into account when attempting to explain variations in actual turnover. McKnight et. al. [24] studied in 2009 the factor that reduces IT turnover intention the most, the job characteristics or the workplace characteristics. They found that workplace characteristics out-predicted job characteristics.

Based on literature discussed above, no comprehensive study has been made for all factors affecting the turnover. Moreover, no such a study has been made on workers in the Middle East region.

\section{PROBLEM STATEMENT AND SOLUTION TECHNIQUE}

\subsection{Problem Statement}

Workers turnover is very critical issue, especially for a third world developed country like Jordan. In the last few years, Jordan started to attract many industries from all over the world by offer the convenient environment to have successful business. Factories in Jordan are distributed over the three largest cities, Amman, Zarqa and Irbid. Many of the factories are located in industrial cities in these largest cities, but other factories still there outside these industrial cities. The industrial cities are Sahab industrial city in Amman, AlDulail industrial city in Zarqa and AlHasan industrial city in Irbid. The establishment of these industrial cities intended to improve and support the industrial sector and introduce 
all possible services for as much industries as possible.

Since Amman, Zarqa and Irbid contain more than $90 \%$ of the Jordanian population; the study was limited to these three cities. The workers turnover from factories in these three largest cities caused instability both in the production capacity and the production quality. Shortage in number of workers leaded to decreasing production capacity, and leaving skilled and experienced works and hiring prospective works leaded to decreasing the products quality. On the other hand, the increase in the workers turnover affected not only the industrial sector and the country economy, but also the Jordanian community and social life of the Jordanian. As the number of factories and industries is increasing, as the workers turnover problem is getting larger. For these reasons this study is trying to investigate this workers turnover issue to find the main reasons which lead to this phenomenon, and so it is the first main step for reducing the effects of this problem.

\subsection{Solution Technique}

A questionnaire was designed such that it includes five main categories; Category $\mathrm{A}$ is the salary, Category B is the working environment, Category C is the helpfulness and corporation of the management, Category $\mathrm{D}$ is worker psychological state and relationships with surrounding environment, Category $\mathrm{E}$ is the services provided by the employer to the employee. Each category contained many questions, and the answers ranged from strongly agree with a load of 5 to strongly disagree with a load of 1 . Strongly agree means that question was not really a reason for turnover. While strongly disagree means this question is a reason for turnover. So, as the average points a question achieve is lower as that question is qualified for being a reason for turnover. On the contrary if the average a question achieve is high, then that means this question is away from being a reason for turnover.

The question was distributed over twenty one factories, seven factories in each of the industrial cities. Seven more factories located in the largest cities but outside the industrial cities were also chosen to be included in this study. In each factory, the $50 \%$ of the sample was from workers who already turned over and left the factory in the last two years, and $50 \%$ of the sample was from people still working in their jobs. Equal number of questionnaires was collected from all factories to be around 80. All questionnaires results were analyzed using Excel and Minitab. A statistical model for analyzing the results was built. A comparison between the averages achieved by each question in the questionnaire was carried out and the main reasons for workers turnover were determined.

The questionnaire is reported in the appendix of this paper.

\subsubsection{AlDulail Industrial City}

AlDulail industrial city represents a village community that is located far from the capital city Amman, where people are relatively poor with lower level of education than people live in big cities like Amman. And so AlDulail city represents the community of people who do not have a main career, like AlHasan industrial city where people live mainly on cultivation, or higher level of education and standards of living, like people live in the capital city, Amman. Table 1 shows a summary for the average values of the questionnaire questions when distributed in the seven factories in AlDulail industrial city. Numerical results in Table 1 shows that criterion E, the services provided by the employer to the employee, has the highest average value of 3.21, which makes it the least important issue 
for workers turnover in that industrial city. Mainly that is related to village community are not looking for superior services, and they accept to live very simple life with basic needs available. On the other hand criterion A, the salary, has the greatest effect on workers turnover with an average value of 2.41. The explanation for this is that AlDulail industrial city is located in relatively poor region, where the effect of world wide inflation is influencing more. But since AlDulail is not a rich city, services by employer there are relatively sufficient and so workers are not expecting more in this direction from their employer, which makes salary the main reason for workers to turn over.

The question that has the highest average was E6, which asks about the general safety and cleaning stuff. Most workers there agreed that the safety and cleaning is not an issue there and so not a possible reason for turnover. On the contrary A1 has the lowest average, which implies that salary is not enough for basic needs in AlDulail industrial city.

Table 1: Summary results of A-E criteria of AlDulail industrial city

\begin{tabular}{|c|c|}
\hline CRITERION & MEAN \\
\hline D1 & $\mathbf{2 . 4 1}$ \\
\hline D2 & $\mathbf{1 . 6 6}$ \\
\hline D3 & $\mathbf{2 . 5 2}$ \\
\hline D4 & $\mathbf{2 . 9 4}$ \\
\hline D5 & $\mathbf{2 . 5 8}$ \\
\hline D6 & $\mathbf{2 . 4 8}$ \\
\hline D7 & $\mathbf{2 . 9 9}$ \\
\hline D8 & $\mathbf{2 . 9 4}$ \\
\hline D9 & $\mathbf{3 . 0 8}$ \\
\hline D10 & $\mathbf{3 . 4 3}$ \\
\hline AVERAGE & \\
D & $\mathbf{2 . 7 1}$ \\
\hline
\end{tabular}

\begin{tabular}{|c|c|c|c|}
\hline CRITERION & MEAN & E7 & 3.48 \\
\hline C1 & $3.3 \sqrt[3]{3}$ & E8 & 3.50 \\
\hline $\mathrm{C} 2$ & 3.01 & E9 & 3.77 \\
\hline C3 & 2.83 & E10 & 2.76 \\
\hline $\mathrm{C4}$ & 2.96 & E11 & 3.17 \\
\hline C5 & $2 . \sqrt{2}$ & E12 & 2.69 \\
\hline C6 & $2 . \sqrt{3}$ & E13 & 3.46 \\
\hline C7 & 2.60 & E14 & 3.89 \\
\hline C8 & \multicolumn{2}{|c|}{ 2.64 AVERAGE } & \\
\hline C9 & \multirow{2}{*}{2.74} & $\mathbf{E}$ & 3.21 \\
\hline C10 & & & \\
\hline \multirow[b]{2}{*}{ C11 } & \multicolumn{2}{|c|}{ CRITERION } & MEAN \\
\hline & 2.61 & A1 & 1.28 \\
\hline \multirow{2}{*}{$\begin{array}{c}\text { AVERAGE } \\
\mathrm{C} \\
\end{array}$} & \multirow{3}{*}{2.81} & A2 & 2.26 \\
\hline & & A3 & 2.99 \\
\hline \multirow{2}{*}{\multicolumn{2}{|c|}{\begin{tabular}{l|l|l}
\multicolumn{2}{|l|}{} & \\
CRITERION & MEAN \\
\end{tabular}}} & A4 & 3.13 \\
\hline & & & \\
\hline B1 & 2.20 & A5 & 2.22 \\
\hline B2 & 2.00 & A6 & 2.16 \\
\hline B3 & & A7 & 2.85 \\
\hline B4 & \multicolumn{2}{|c|}{ 3.09 ANERAGE } & \\
\hline B5 & 2.33 & A & 2.41 \\
\hline B6 & 2.74 & & \\
\hline
\end{tabular}

\begin{tabular}{|c|c|}
\hline B7 & $\mathbf{1 . 8 9}$ \\
\hline B8 & $\mathbf{2 . 3 2}$ \\
\hline B9 & $\mathbf{2 . 6 4}$ \\
\hline B10 & $\mathbf{3 . 0 2}$ \\
\hline B11 & $\mathbf{2 . 8 0}$ \\
\hline B12 & $\mathbf{1 . 9 8}$ \\
\hline B13 & $\mathbf{3 . 1 5}$ \\
\hline B14 & $\mathbf{2 . 1 4}$ \\
\hline & \\
B15 & $\mathbf{2 . 9 6}$ \\
\hline B16 & $\mathbf{2 . 3 0}$ \\
\hline B17 & $\mathbf{2 . 7 6}$ \\
\hline B18 & $\mathbf{2 . 9 8}$ \\
\hline B19 & $\mathbf{3 . 1 5}$ \\
\hline B20 & $\mathbf{3 . 3 6}$ \\
\hline B21 & $\mathbf{2 . 5 6}$ \\
\hline AVERAGE & \\
B & $\mathbf{2 . 6 4}$ \\
\hline
\end{tabular}

\begin{tabular}{|c|c|}
\hline CRITERION & MEAN \\
\hline E1 & 2.55 \\
\hline E2 & 2.84 \\
\hline E3 & 2.78 \\
\hline E4 & 3.11 \\
\hline E5 & 3.00 \\
\hline E6 & 3.95 \\
\hline
\end{tabular}

\subsubsection{Sahab Industrial City}

Sahab industrial city is located near the capital city Amman. People working in that industrial city usually live in Amman. Results of the questionnaire in that industrial city are summarized in Table 2. They show that the criterion $\mathrm{C}$ has the highest average of 3.0, to be the least effect reason for workers turnover in Sahab industrial city. So, the management is helpful in Sahab industrial city and that reduces workers turnover there. 
The question that achieved the highest average was C2 that talk about the corporation and helpfulness of the management when workers have accidents. Salary again is an issue to force the workers to leave their jobs in Sahab industrial city.

The lowest average was for criterion A, with a value of 2.38. that average was even lower than that corresponding average of AlDulail industrial city. That was expected result as people work in Sahab industrial city mostly live in Amman as the questionnaire shows, and Amman is very expensive compared to AlDulail and AlHasan cities. So, workers there may suffer from low salaries more than workers of AlDulail industrial city.

Table 2: Summary results of A-E criteria of Sahab industrial city

\begin{tabular}{|c|c|}
\hline CRITERION & MEAN \\
\hline D1 & $\mathbf{3 . 1 1}$ \\
\hline D2 & $\mathbf{2 . 2 7}$ \\
\hline D3 & $\mathbf{2 . 6 2}$ \\
\hline D4 & $\mathbf{3 . 2 6}$ \\
\hline D5 & $\mathbf{2 . 8 6}$ \\
\hline D6 & $\mathbf{2 . 6 3}$ \\
\hline D7 & $\mathbf{3 . 2 4}$ \\
\hline D8 & $\mathbf{3 . 0 0}$ \\
\hline D9 & $\mathbf{2 . 6 2}$ \\
\hline D10 & $\mathbf{3 . 4 8}$ \\
\hline AVERAGE & \\
D & $\underline{\mathbf{2 . 9 1}}$ \\
\hline
\end{tabular}

\begin{tabular}{|c|c|c|c|}
\hline & & E7 & 3.07 \\
\hline CRITERION & MEAN & E8 & 3.37 \\
\hline C1 & 2.74 & E9 & 2.63 \\
\hline $\mathrm{C2}$ & 3.45 & E10 & 2.59 \\
\hline C3 & $3.3 \sqrt{3}$ & E11 & 2.97 \\
\hline C4 & 3.26 & E12 & 3.11 \\
\hline C5 & 2.90 & E13 & 3.48 \\
\hline C6 & 2.62 & E14 & 3.06 \\
\hline C7 & \multicolumn{2}{|c|}{ 2.79 AVERAGE } & \multirow[b]{2}{*}{$\underline{2.80}$} \\
\hline C8 & 2.74 & $\mathbf{E}$ & \\
\hline C9 & 2.88 & & \\
\hline $\mathrm{C10}$ & \multicolumn{2}{|c|}{ 3.13CRITERION } & MEAN \\
\hline & \multirow[b]{2}{*}{3.21} & A1 & 1.29 \\
\hline C11 & & A2 & 2.48 \\
\hline AVERAGE & \multirow[b]{2}{*}{$3.0 \overline{0}$} & A3 & 3.10 \\
\hline $\mathrm{C}$ & & A4 & 2.24 \\
\hline CRITERION & MEAN & A5 & 2.38 \\
\hline B1 & $2 . \$ 8$ & A6 & 2.20 \\
\hline B2 & $2 . \$ 6$ & A7 & 3.01 \\
\hline B3 & \multicolumn{2}{|c|}{ 293AVERAGE } & \multirow[b]{2}{*}{$\underline{2.38}$} \\
\hline B4 & 2.72 & $\mathbf{A}$ & \\
\hline B5 & 1.75 & & \\
\hline B6 & 1.77 & & \\
\hline
\end{tabular}

\begin{tabular}{|c|c|}
\hline B7 & $\mathbf{1 . 8 8}$ \\
\hline B8 & $\mathbf{2 . 3 6}$ \\
\hline B9 & $\mathbf{2 . 9 3}$ \\
\hline B10 & $\mathbf{3 . 0 8}$ \\
\hline B11 & $\mathbf{2 . 5 3}$ \\
\hline B13 & $\mathbf{2 . 2 6}$ \\
\hline B14 & $\mathbf{2 . 4 4}$ \\
\hline & $\mathbf{2 . 1 0}$ \\
\hline B15 & $\mathbf{2 . 4 0}$ \\
\hline B16 & $\mathbf{1 . 9 3}$ \\
\hline B17 & $\mathbf{2 . 1 2}$ \\
\hline B18 & $\mathbf{2 . 0 6}$ \\
\hline B19 & $\mathbf{3 . 0 5}$ \\
\hline B20 & $\mathbf{3 . 0 3}$ \\
\hline B21 & $\mathbf{2 . 0 0}$ \\
\hline AVERAGE & \\
B & $\underline{\mathbf{2 . 4 1}}$ \\
\hline
\end{tabular}

\begin{tabular}{|c|c|}
\hline CRITERION & MEAN \\
\hline E1 & 2.43 \\
\hline E2 & 1.94 \\
\hline E3 & 2.38 \\
\hline E4 & 2.94 \\
\hline E5 & 2.42 \\
\hline E6 & 2.85 \\
\hline
\end{tabular}

\subsubsection{IHasan Industrial City}

Although AlHasan industrial city is located in the north far from the capital city Amman, it shares same reasons for workers turnover with Sahab and AlDulail industrial cities. The lowest average was for the criterion A with a 2.43 value as shown in Table 3. It is a little higher than that corresponding value for Sahab and AlDulail industrial cities. That is mainly related to life nature around AlHasan industrial city that is located in the cultivation community and life there is much cheaper than that in the capital city Amman. The criterion with the highest average was D, worker psychological state and relationships with surrounding environment. Usually 
communities depending on cultivation in their lives have better psychological state and relationships with surrounding environment, than communities of big cities.

Table 3: Summary results of A-E criteria of AlHasan industrial city

\begin{tabular}{|c|c|}
\hline CRITERION & MEAN \\
\hline D1 & $\mathbf{3 . 0 1}$ \\
\hline D2 & $\mathbf{2 . 8 2}$ \\
\hline D3 & $\mathbf{2 . 8 6}$ \\
\hline D4 & $\mathbf{3 . 2 3}$ \\
\hline D5 & $\mathbf{3 . 0 7}$ \\
\hline D6 & $\mathbf{2 . 8 5}$ \\
\hline D7 & $\mathbf{3 . 4 5}$ \\
\hline D8 & $\mathbf{3 . 0 9}$ \\
\hline D9 & $\mathbf{3 . 0 5}$ \\
\hline D10 & $\mathbf{3 . 3 9}$ \\
\hline AVERAGE & \\
D & $\underline{\mathbf{3 . 0 8}}$ \\
\hline
\end{tabular}

\begin{tabular}{|c|c|c|c|}
\hline CRITERION & MEAN & E7 & 3.41 \\
\hline C1 & 2.87 & E8 & 3.66 \\
\hline $\mathrm{C2}$ & 3.00 & E9 & 3.72 \\
\hline C3 & 2.01 & E10 & 3.39 \\
\hline C4 & 3.25 & E11 & 3.27 \\
\hline C5 & 3.02 & E12 & 3.17 \\
\hline C6 & 3.43 & E13 & 3.46 \\
\hline C7 & 3.16 & E14 & 3.26 \\
\hline C8 & \multirow{2}{*}{\multicolumn{2}{|c|}{ 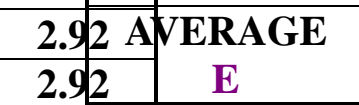 }} & \multirow[b]{2}{*}{$\underline{\underline{3.36}}$} \\
\hline C9 & & & \\
\hline $\mathrm{C10}$ & 3.04 & & \multirow[b]{2}{*}{ MEAN } \\
\hline & \multirow{2}{*}{$3.0 \frac{\mathrm{CF}}{\frac{6}{6}}$} & ITERION & \\
\hline C11 & & A1 & 1.482 \\
\hline AVERAGE & \multirow[b]{2}{*}{3.05} & A2 & 2.416 \\
\hline C & & A3 & 2.352 \\
\hline & \multicolumn{2}{|r|}{ A4 } & 2.963 \\
\hline CRITERION & MEAN & A5 & 2.68 \\
\hline B1 & $2 . \$ 1$ & A6 & 2.614 \\
\hline $\mathrm{B} 2$ & 2.32 & A7 & 2.677 \\
\hline B3 & \multicolumn{2}{|c|}{ 2.\$0 AYERAGE } & \multirow{4}{*}{$\underline{2.455}$} \\
\hline B4 & 2.70 & A & \\
\hline B5 & 2.37 & & \\
\hline B6 & 2.41 & & \\
\hline
\end{tabular}

\begin{tabular}{|c|c|}
\hline B7 & $\mathbf{2 . 2 6}$ \\
\hline B8 & $\mathbf{2 . 5 4}$ \\
\hline B9 & $\mathbf{2 . 4 7}$ \\
\hline B10 & $\mathbf{2 . 4 8}$ \\
\hline B11 & $\mathbf{2 . 5 6}$ \\
\hline B12 & $\mathbf{2 . 3 3}$ \\
\hline B13 & $\mathbf{2 . 9 2}$ \\
\hline B14 & $\mathbf{2 . 4 6}$ \\
\hline & \\
B15 & $\mathbf{2 . 9 9}$ \\
\hline B16 & $\mathbf{2 . 5 3}$ \\
\hline B17 & $\mathbf{1 . 7 6}$ \\
\hline B18 & $\mathbf{1 . 8 6}$ \\
\hline B19 & $\mathbf{2 . 8 0}$ \\
\hline B20 & $\mathbf{2 . 8 8}$ \\
\hline B21 & $\mathbf{1 . 7 3}$ \\
\hline AVERAGE & \\
B & $\mathbf{2 . 4 7}$ \\
\hline
\end{tabular}

\begin{tabular}{|c|c|}
\hline CRITERION & MEAN \\
\hline E1 & 2.81 \\
\hline E2 & 2.78 \\
\hline E3 & 3.64 \\
\hline E4 & 3.47 \\
\hline E5 & 3.09 \\
\hline E6 & 3.94 \\
\hline
\end{tabular}

\subsubsection{Industrial Cities in Jordan}

Industrial cities are a healthy phenomenon that started to appear in Jordan in the last two decades. Instead of having factories distributed here and there all around the city, all or most factories located in that city are placed in one region that has special services and treatments, called the industrial city. Table 4 summarizes the results of the three main industrial cities in Jordan. Workers in the three industrial cities agree that the salary is their main concern to leave their jobs there. The next factor that might be a reason for workers turnover from industrial cities was the working condition and environment. On the other hand a reasonable satisfaction was achieved for the services provided by the employer. 
Table 4: Summary results of A-E criteria of industrial cities in Jordan

\begin{tabular}{|c|c|}
\hline CRITERION & MEAN \\
\hline D1 & 2.85 \\
\hline D2 & 2.25 \\
\hline D3 & 2.67 \\
\hline D4 & 3.14 \\
\hline D5 & 2.84 \\
\hline D6 & 2.65 \\
\hline D7 & 3.23 \\
\hline D8 & $\mathbf{3 . 0 1}$ \\
\hline D9 & $\mathbf{2 . 9 2}$ \\
\hline D10 & $\mathbf{3 . 4 3}$ \\
\hline AVERAGE D & $\underline{\mathbf{2 . 9 0}}$ \\
\hline
\end{tabular}

\begin{tabular}{|c|c|c|}
\hline CRITERION & MEAN & E7 \\
\hline C1 & 2.98 & E8 \\
\hline C2 & 3.16 & E9 \\
\hline $\mathrm{C} 3$ & 3.02 & E10 \\
\hline $\mathrm{C} 4$ & 3.16 & F11 \\
\hline C5 & 2.88 & Fe? \\
\hline C6 & 2.93 & \\
\hline C7 & 2.85 & E13 \\
\hline C8 & 2.77 & E14 \\
\hline C9 & $2.85^{\mathrm{AVI}}$ & RAGE E \\
\hline C10 & 2.98 & \\
\hline C11 & $2.92^{R}$ & TERION \\
\hline AVERAGE C & $\underline{2.95}$ & A1 \\
\hline CRITERION & MEAN & A2 \\
\hline B1 & 2.56 & A3 \\
\hline $\mathrm{B} 2$ & 2.33 & A4 \\
\hline B3 & 2.95 & A5 \\
\hline B4 & 2.84 & A6 \\
\hline B5 & 2.15 & A7 \\
\hline B6 & $2.3 \mathrm{~A}^{\mathrm{V}}$ & RAGE A \\
\hline
\end{tabular}

3.32

3.51

3.37

2.91

3.14

2.99

3.47

3.40

$\underline{\mathbf{3 . 1 3}}$

\begin{tabular}{|c|c|}
\hline B7 & $\mathbf{2 . 0 1}$ \\
\hline B8 & $\mathbf{2 . 4 1}$ \\
\hline B9 & $\mathbf{2 . 6 8}$ \\
\hline B10 & $\mathbf{2 . 8 6}$ \\
\hline B11 & $\mathbf{2 . 6 3}$ \\
\hline B12 & $\mathbf{2 . 1 9}$ \\
\hline B13 & $\mathbf{2 . 8 3}$ \\
\hline B14 & $\mathbf{2 . 2 3}$ \\
\hline B15 & $\mathbf{2 . 7 8}$ \\
\hline B16 & $\mathbf{2 . 2 5}$ \\
\hline B17 & $\mathbf{2 . 2 1}$ \\
\hline B18 & $\mathbf{2 . 3 0}$ \\
\hline B19 & $\mathbf{3 . 0 0}$ \\
\hline B20 & $\mathbf{3 . 0 9}$ \\
\hline B21 & $\mathbf{2 . 0 9}$ \\
\hline AVERAGE B & $\mathbf{2 . 5 1}$ \\
\hline & \\
\hline & \\
\hline & \\
\hline & \\
\hline & \\
\hline & \\
\hline & \\
\hline & \\
\hline & \\
\hline & \\
\hline & \\
\hline & \\
\hline
\end{tabular}

\subsubsection{Factories Outside Industrial Cities in Jordan}

Seven factories located in the capital city Amman but outside any of the three industrial cities were included in survey of this study. The results of these factories are summarized in Table 5. Compared to results of factories located in industrial cities, it can be noticed here that the main reason for possible workers turnover is the worker psychological state and relationships with surrounding environment, in contrast to salary that was the main reason for workers turnover in factories located inside the industrial cities. That might be related to the fact that factories outside the industrial cities usually look for professional and experienced workers and so the pay them good salaries and of course expect from 
them more. That put the workers under stress all the time and makes the main reason for possible turnover is the psychological state of the workers. Investigating all results in Table 5 indicated that averages of all criteria are low compared to corresponding criteria for industrial cities. Which means the general satisfaction of workers in factories inside industrial cities is much more than the satisfaction of workers in factories outside industrial cities. That might be related to services and facilities provided by the government to those industrial cities. So, generally the workers turnover problem severity is more for factories located outside industrial cities, especially those factories looking for profession and experienced workers.

Table 5: Summary results of A-E criteria of factories outside industrial cities in Jordan

\begin{tabular}{|c|c|}
\hline CRITERION & MEAN \\
\hline D1 & $\mathbf{1 . 4 1}$ \\
\hline D2 & $\mathbf{1 . 6 3}$ \\
\hline D3 & $\mathbf{1 . 9 4}$ \\
\hline D4 & $\mathbf{1 . 4 7}$ \\
\hline D5 & $\mathbf{2 . 4 1}$ \\
\hline D6 & $\mathbf{2 . 4 8}$ \\
\hline D7 & $\mathbf{2 . 9 2}$ \\
\hline
\end{tabular}

\begin{tabular}{|c|c|c|c|}
\hline CRITERION & MEAN & D8 & 2.60 \\
\hline C1 & 2.67 & D9 & 1.48 \\
\hline $\mathrm{C2}$ & 2.89 & D10 & 1.34 \\
\hline C3 & 2.91 & \multirow{2}{*}{$\begin{array}{c}\text { VERAGE } \\
\text { D }\end{array}$} & \multirow[b]{2}{*}{$\underline{1.97}$} \\
\hline C4 & 2.99 & & \\
\hline C5 & 2.91 & & \\
\hline C6 & 2.90 & & \\
\hline C7 & 2.82 & & \\
\hline
\end{tabular}

\begin{tabular}{|c|c|} 
C8 & 2.75 \\
\hline C9 & 2.80 \\
\hline C10 & 2.66 \\
\hline C11 & 2.74 \\
\hline $\begin{array}{c}\text { AVERAGE } \\
\text { C }\end{array}$ & $\underline{\mathbf{2 . 8 2}}$ \\
\hline
\end{tabular}

\begin{tabular}{|c|c|}
\hline CRITERION & MEAN \\
\hline E1 & 1.94 \\
\hline E2 & 1.69 \\
\hline E3 & 2.74 \\
\hline E4 & 1.49 \\
\hline E5 & 1.41 \\
\hline E6 & 3.40 \\
\hline E7 & 2.80 \\
\hline E8 & 3.22 \\
\hline E9 & 1.29 \\
\hline E10 & 2.56 \\
\hline E11 & 2.57 \\
\hline E12 & 2.40 \\
\hline E13 & 2.96 \\
\hline
\end{tabular}

\begin{tabular}{|c|c|c|c|}
\hline CRITERION & MEAN & E14 & 2.40 \\
\hline B1 & \multicolumn{2}{|c|}{2.23 AVERAGE } & \multirow[b]{2}{*}{$\underline{2.35}$} \\
\hline $\mathrm{B2}$ & $2.0 \phi$ & $\mathbf{E}$ & \\
\hline B3 & 2.97 & & \\
\hline B4 & \multicolumn{2}{|c|}{ 2.74 CRITERION } & MEAN \\
\hline B5 & $1.4 \$$ & A1 & 2.39 \\
\hline B6 & $2.2 \phi$ & A2 & 2.60 \\
\hline B7 & 1.8 & A3 & 2.68 \\
\hline B8 & 2.32 & A4 & 3.74 \\
\hline B9 & 2.54 & A5 & 3.02 \\
\hline B10 & 2.8 & A6 & 2.96 \\
\hline B11 & 2.17 & A7 & 2.81 \\
\hline B12 & $2.4 \$ \quad A$ & AVERAGE & \\
\hline B13 & 2.51 & $\mathbf{A}$ & 2.89 \\
\hline
\end{tabular}

\begin{tabular}{|c|c|}
\hline B14 & $\mathbf{2 . 6 4}$ \\
\hline & \\
B15 & $\mathbf{3 . 0 7}$ \\
\hline B16 & $\mathbf{2 . 4 2}$ \\
\hline B17 & $\mathbf{1 . 4 1}$ \\
\hline B18 & $\mathbf{1 . 3 1}$ \\
\hline B19 & $\mathbf{2 . 7 0}$ \\
\hline B20 & $\mathbf{2 . 9 3}$ \\
\hline B21 & $\mathbf{1 . 3 9}$ \\
\hline AVERAGE B & $\underline{\mathbf{2 . 3 0}}$ \\
\hline
\end{tabular}

\subsubsection{Overall Turnover Results}

Combining the results of the factories inside the industrial cities and the results of factories located outside the industrial cities to achieve an overall idea about the workers turnover problem in the industrial sector in Jordan, gave results summarized in Table 6. As results show the main reason for possible turnover in industrial sector in Jordan is the working conditions and environment. Then the salary factor comes to be the second factor for turnover. Other factors have less effect on turnover issue. The least factor affecting the turnover is criterion E, the services provided by the employer. It looks that employee are satisfied with serviced provided. Average values for all criteria show that all of them are 
above 2.5 except criterion B. That means the only dissatisfaction is in the working conditions and environment. But other factors are not really issues for turnover.

Table 6: Summary results of A-E criteria of industrial sector in Jordan

\begin{tabular}{|c|c|}
\hline CRITERION & MEAN \\
\hline D1 & $\mathbf{2 . 4 9}$ \\
\hline D2 & $\mathbf{2 . 1 0}$ \\
\hline D3 & $\mathbf{2 . 4 8}$ \\
\hline D4 & $\mathbf{2 . 7 3}$ \\
\hline D5 & $\mathbf{2 . 7 3}$ \\
\hline D6 & $\mathbf{2 . 6 1}$ \\
\hline D7 & $\mathbf{3 . 1 5}$ \\
\hline
\end{tabular}

\begin{tabular}{|c|c|c|c|}
\hline CRITERION & MEAN & D8 & 2.91 \\
\hline C1 & 2.90 & D9 & 2.56 \\
\hline $\mathrm{C} 2$ & 3.09 & D10 & 2.91 \\
\hline C3 & \multicolumn{2}{|c|}{ 2.99 AVERAGE } & \multirow[b]{2}{*}{2.67} \\
\hline C4 & 3.11 & $\mathrm{D}$ & \\
\hline C5 & 2.89 & & \\
\hline C6 & 2.92 & & \\
\hline C7 & 2.84 & & \\
\hline
\end{tabular}

\begin{tabular}{|c|c|} 
C8 & 2.76 \\
\hline C9 & 2.83 \\
\hline C10 & 2.90 \\
\hline C11 & 2.87 \\
\hline $\begin{array}{c}\text { AVERAGE } \\
\text { C }\end{array}$ & $\underline{\mathbf{2 . 9 2}}$ \\
\hline
\end{tabular}

\begin{tabular}{|c|c|}
\hline CRITERION & MEAN \\
\hline E1 & 2.43 \\
\hline E2 & 2.31 \\
\hline E3 & 2.88 \\
\hline E4 & 2.75 \\
\hline E5 & 2.48 \\
\hline E6 & 3.53 \\
\hline E7 & 3.19 \\
\hline E8 & 3.43 \\
\hline E9 & 2.85 \\
\hline E10 & 2.82 \\
\hline E11 & 3.00 \\
\hline E12 & 2.84 \\
\hline E13 & $\mathbf{3 . 3 4}$ \\
\hline E14 & $\mathbf{3 . 1 5}$ \\
\hline
\end{tabular}

\begin{tabular}{|c|c|c|c|}
\hline CRITERION & MEANA & \multirow{2}{*}{$\begin{array}{l}\text { VERAGE } \\
\text { E }\end{array}$} & \multirow[b]{2}{*}{$\underline{2.93}$} \\
\hline B1 & 2.48 & & \\
\hline B2 & 2.26 & & \\
\hline B3 & \multicolumn{2}{|c|}{ 2.96CRITERION } & MEAN \\
\hline B4 & 2.81 & A1 & 1.61 \\
\hline B5 & 1.97 & A2 & 2.44 \\
\hline B6 & 2.29 & A3 & 2.78 \\
\hline B7 & 1.98 & A4 & 3.02 \\
\hline B8 & 2.38 & \multirow[b]{2}{*}{ A5 } & \multirow[b]{2}{*}{2.57} \\
\hline B9 & 2.64 & & \\
\hline B10 & 2.84 & A6 & 2.49 \\
\hline B11 & 2.51 & A7 & 2.84 \\
\hline B12 & \multicolumn{2}{|c|}{ 2.26 AVERAGE } & \multirow{3}{*}{2.53} \\
\hline B13 & 2.75 & A & \\
\hline B14 & 2.34 & & \\
\hline
\end{tabular}

\begin{tabular}{|c|c|} 
& \\
B15 & $\mathbf{2 . 8 5}$ \\
\hline B16 & $\mathbf{2 . 3 0}$ \\
\hline B17 & $\mathbf{2 . 0 1}$ \\
\hline B18 & $\mathbf{2 . 0 5}$ \\
\hline B19 & $\mathbf{2 . 9 2}$ \\
\hline B20 & $\mathbf{3 . 0 5}$ \\
\hline B21 & $\mathbf{1 . 9 2}$ \\
\hline $\begin{array}{c}\text { AVERAGE } \\
\text { B }\end{array}$ & $\underline{\mathbf{2 . 4 6}}$ \\
\hline
\end{tabular}




\section{DISCUSSION OF THE RESULTS}

The data collected and summarized in Tables 1-6 were analyzed and a statistical model for workers turn over in Jordanian factories was built using Excel and Minitab.

From Table 7; it is clear that the salary scale is the only criterion which is better outside the industrial zones from the inside ones. The overall satisfaction for the employees is 2.78 inside the industrial zone while it is 2.46 outside theses zones. This indicates that there is better employee's satisfaction inside the zones better than outside. Many facilities were available inside the zones and also there is good infrastructure in such closed cities. It is noted also from the above table, that the highest satisfaction for employees is the services provided by the employer inside the industrial zones. All of these findings are also illustrated in Figure 1 below.

Table 7: Comparison between the averages of the 5 criteria for inside and outside industrial cities

\begin{tabular}{|c|ccccc|c|}
\hline Category & A & B & C & D & E & Average \\
Inside & 2.41 & 2.51 & 2.96 & 2.90 & 3.13 & 2.78 \\
\hline Outside & 2.89 & 2.30 & 2.82 & 1.97 & 2.35 & 2.46 \\
\hline
\end{tabular}

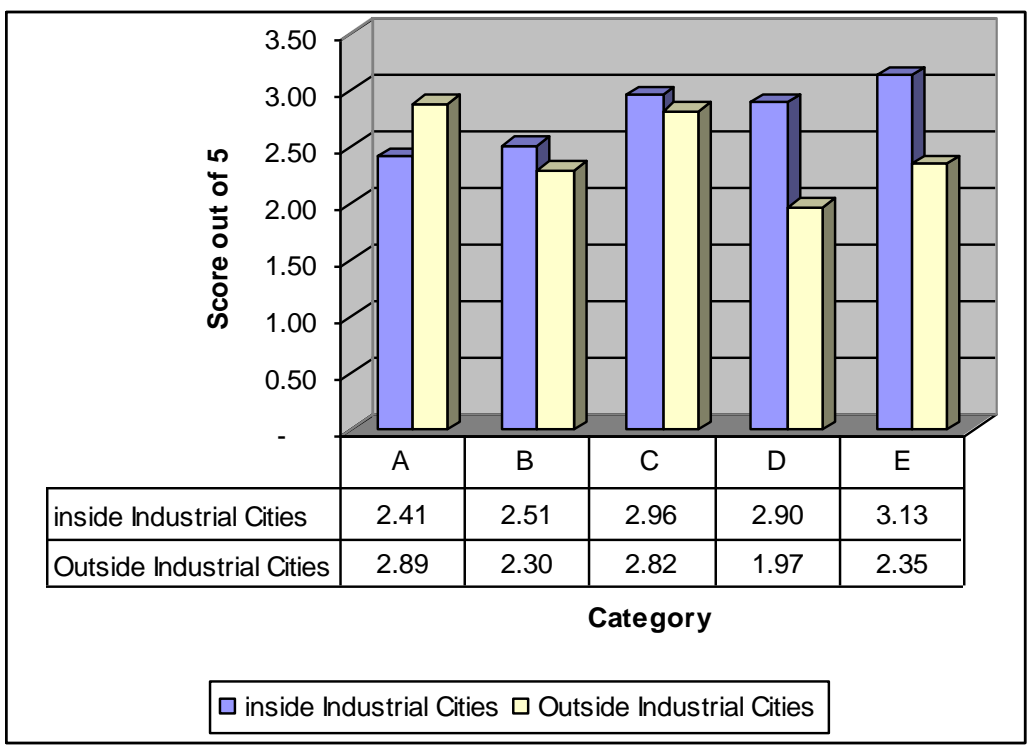

Figure 1: Comparison between the averages of the 5 criteria for inside and outside industrial cities

Table 8 shows a comparison between the different cities inside the industrial zone. It is clear that the Al- Hassan city has the highest over all average of employee's satisfaction (2.89), against the lowest (2.7) in Sahab city. Figure 2 shows that in Al-Dulail city, the working conditions and environment scored the best (2.64) among the other industrial cities, while in Sahab city; the salary scale scored the lowest level of satisfaction among all the industrial cities. 
Table 8: Summary results of different categories in different cities within industrial

\begin{tabular}{|c|c|c|c|c|c|c|}
\hline & \multicolumn{3}{|c|}{ zones } & \multirow[b]{2}{*}{$\mathrm{D}$} & \multirow[b]{2}{*}{$\mathrm{E}$} \\
\hline & & A & B & $\mathrm{C}$ & & \\
\hline & 1 & $\underline{2.25}$ & 2.60 & 2.74 & 2.68 & 3.60 \\
\hline & 2 & 2.39 & 2.61 & 2.86 & 2.69 & 3.08 \\
\hline & 3 & 2.29 & 2.68 & 2.70 & 2.59 & 2.76 \\
\hline & 4 & 2.55 & 2.65 & 2.85 & 2.74 & 2.94 \\
\hline & 5 & 2.52 & 2.68 & 2.94 & 2.85 & 3.32 \\
\hline & 6 & 2.42 & 2.67 & 2.88 & 2.70 & 3.50 \\
\hline AlDulail & 7 & 2.48 & 2.61 & 2.72 & 2.67 & 3.28 \\
\hline 2.76 & AV. & 2.41 & 2.64 & 2.81 & 2.71 & 3.21 \\
\hline & 1 & 2.35 & 2.29 & 2.99 & 3.01 & 2.59 \\
\hline & 2 & 2.45 & 2.36 & 2.94 & 2.67 & 2.94 \\
\hline & 3 & 2.34 & 2.42 & 3.07 & 2.91 & 2.65 \\
\hline & 4 & 2.57 & 2.58 & 3.07 & 2.96 & 2.83 \\
\hline & 5 & 2.31 & 2.28 & 2.93 & 2.72 & 2.91 \\
\hline & 6 & 2.30 & 2.44 & 3.06 & 3.01 & 2.94 \\
\hline Sahab & 7 & 2.30 & 2.44 & 3.06 & 3.01 & 2.94 \\
\hline 2.70 & AV. & 2.37 & 2.40 & 3.02 & 2.90 & 2.83 \\
\hline & 1 & 2.49 & $\underline{2.86}$ & $\underline{3.41}$ & $\underline{3.19}$ & $\underline{4.01}$ \\
\hline & 2 & 2.56 & 2.34 & 3.18 & 3.06 & 3.42 \\
\hline & 3 & 2.40 & 2.33 & 3.04 & 3.13 & 2.94 \\
\hline & 4 & 2.39 & 2.55 & 2.96 & 3.18 & 3.63 \\
\hline & 5 & 2.45 & 2.43 & 2.80 & 3.11 & 3.25 \\
\hline & 6 & 2.38 & 2.39 & 3.06 & 2.99 & 3.24 \\
\hline Alhasan & 7 & 2.52 & 2.41 & 2.90 & 2.91 & 3.05 \\
\hline 2.89 & AV. & 2.45 & 2.47 & 3.05 & 3.08 & 3.36 \\
\hline
\end{tabular}




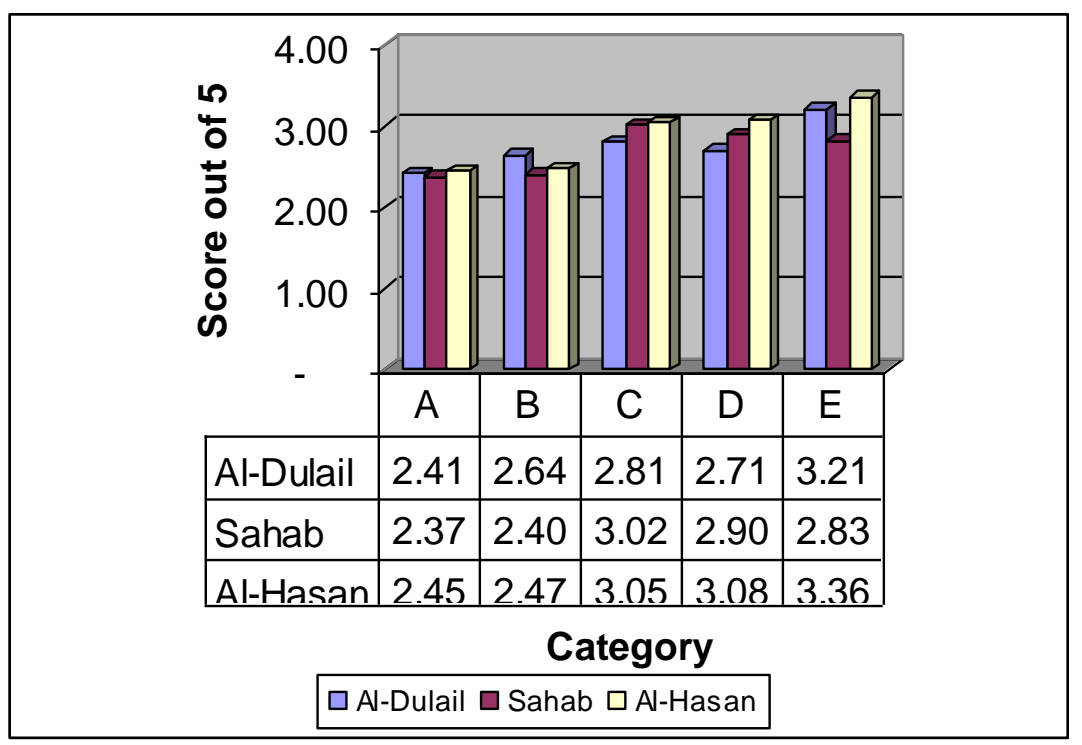

Figure 2: Comparison between different cities inside industrial zones

When go through the analysis of the data of factories outside industrial zones, shown in Table 9, it is clearly noted that the salary category is scored that highest among the different categories, while category D; "Worker Psychological State and Relationships with Surrounding Environment" scored the lowest. 1.97 Among all categories. This indicates a low relationship between the workers and the surrounding environment. This means that relations with local communities and the workers should be strengthen and improved. This is one of the top management responsibilities.

Table 9: Analysis of the outside industrial zones results

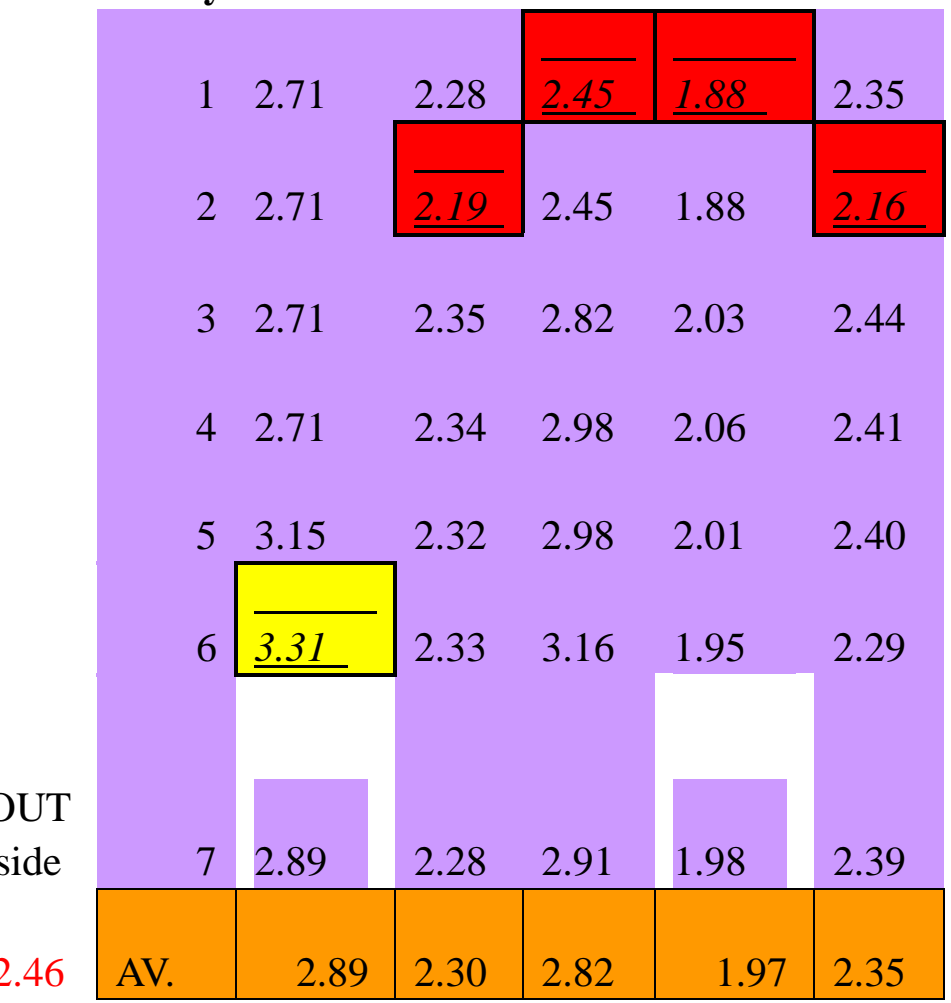


Figure 3, represents the box plots for the different categories of the study. It is noted the category $\mathrm{E}$, has the biggest dispersion and hence, has the largest standard deviation. On the other hand, category $\mathrm{C}$; have the smallest dispersion and the standard deviation. In category $\mathrm{D}$; more than $50 \%$ of the employees there responses were varied between 2.5 and 3.20, which will lead to inter quartile range (IQR) of 0.70 and the range is 1.9 , which is considered a big range. The IQR for category $\mathrm{C}$ is 0.27 and the range is 0.9. The maximum average of employees' satisfaction can be seen in $\mathrm{C}$ category, while the minimum belonged to category $\mathrm{B}$.

The overall score comparison for the employee's satisfaction in the different locations is presented in Figure 4. Al-Hasan city scored the highest employees satisfaction (2.89) among the different locations, while the factories outside the industrial zones scored only 2.46; which is the least among the different locations. Inside the industrial zones; Al-Hasan city is also scored the highest employees satisfaction compared to Sahab city which scored the lowest. The reason behind that behind this is that Sahab city is the oldest industrial city in Jordan, while Al-Hasan is the latest one.

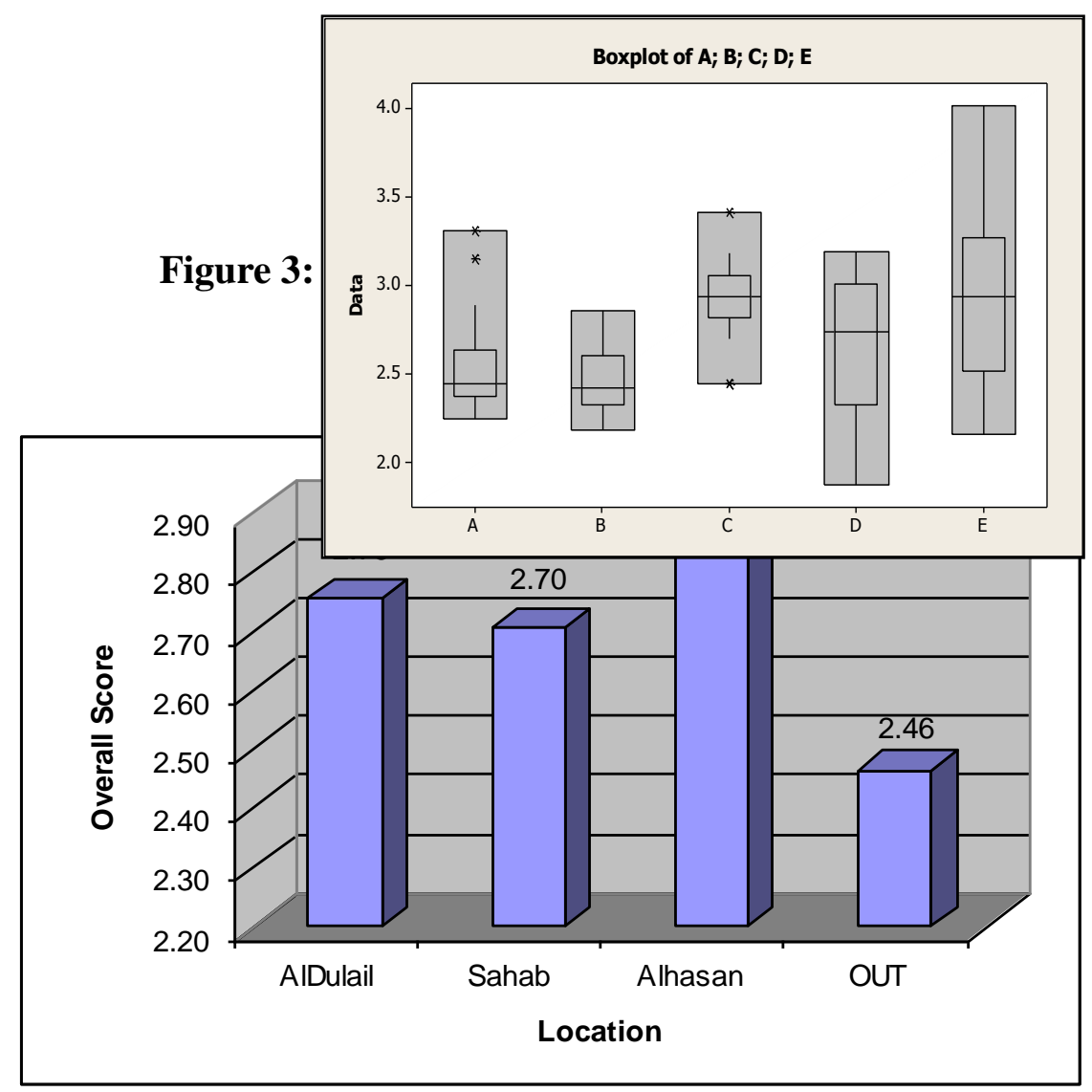

Figure 4: Over all score in different locations

Figure 4 shows three categories of turned over workers based on their salaries. It is was found that $60 \%$ of employees have a salary less than 160 JDs which considered as very low salary which will not cover the minimum leveling requirements. This will be 
reflected to the employees' satisfaction negatively. As expected, as salary is getting less, the workers turnover problem is getting bigger. Even though, the turnover problem still there even for salaries higher than 200 JDs.

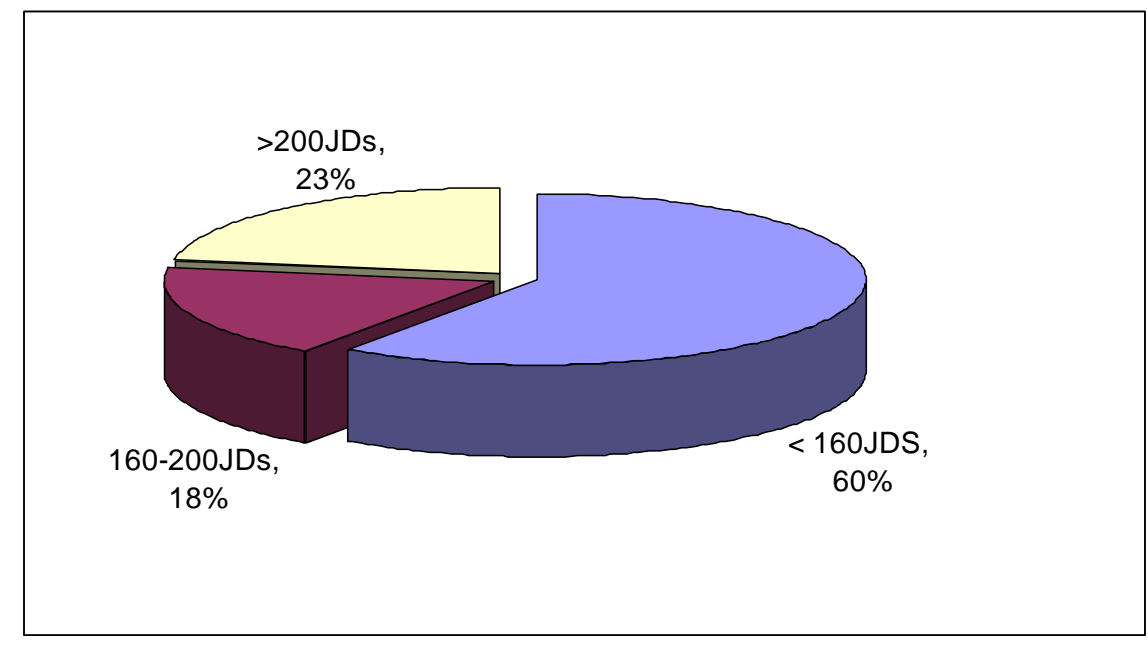

Figure 4: The effect of salary on workers turnover

The relationship between the amount of salary and the employees' satisfaction were studied in figure 5. As the salary increased, the satisfaction will increase with approximately linear proportional relationship.

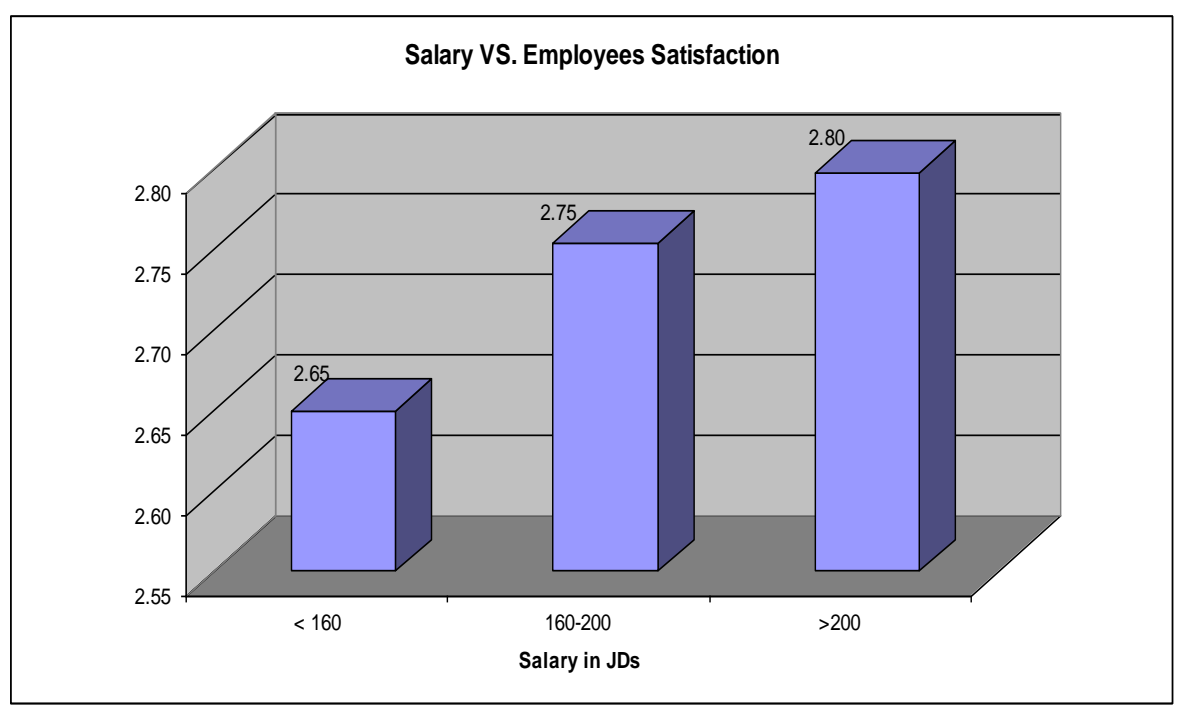

Figure 5: The effect of salary on workers satisfaction

The next factor that was studied is the effect of the resident location on the workers turnover. Figure 6 shows that about $34 \%$ of the workers turned over are resident in Irbid 
and about $37 \%$ of them are in Amman region. In Zarqa and its surrounding there is about $25 \%$ only. Of course living in Amman, the capital of Jordan, requires higher salary to satisfy all expensive requirements. Whereas living in a public city like Zarqa, where living standards are lower, makes low salary more sufficient to satisfy life requirements, and so the turnover problem there is less. Irbid represent the case in between Amman and Zarqa, and so turnover percentage is in between too.

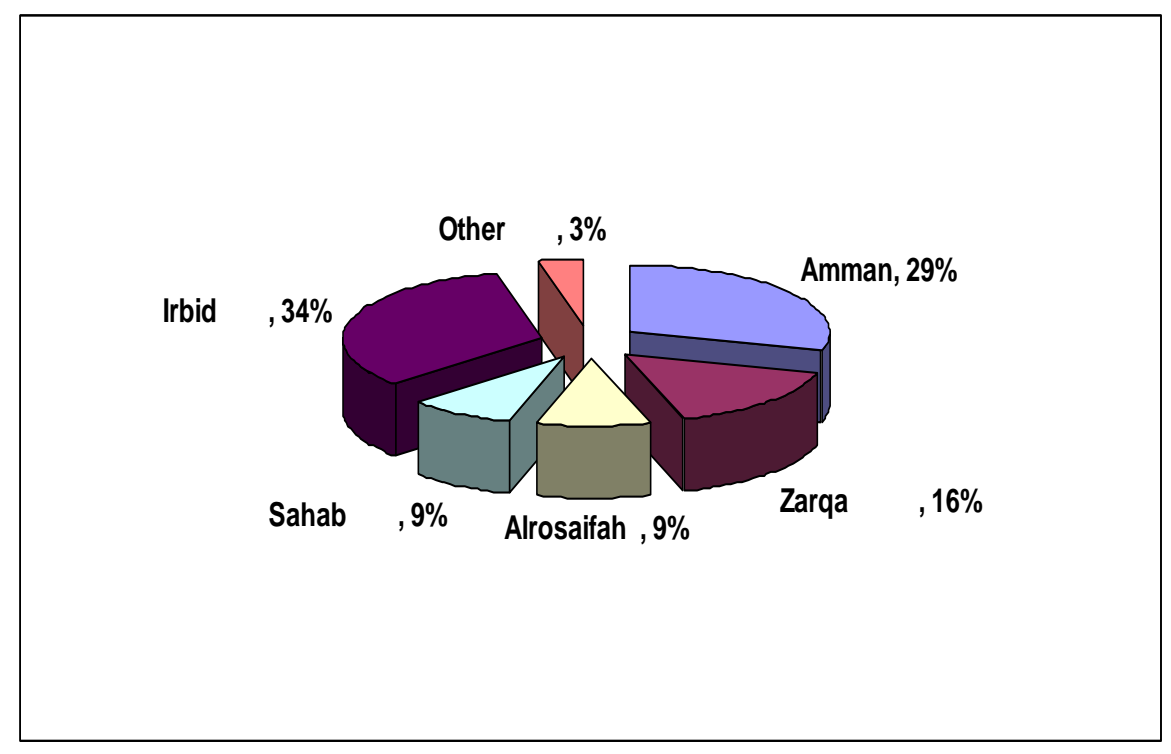

Figure 6: The effect of residency on workers turnover

Figure 7 shows the analyses of satisfaction of these categories related to their location of residency. It is clear that the lowest is in Amman, and the highest in Irbid. These results agreed with the fact that the life style in Amman is higher than the one in Irbid. One more factor that affected this result is the nature of people living in Amman and people living in Zarqa and Irbid. Irbid residents have mostly farming nature, that Irbid is composed of many small villages. Those simple people are usually less complaining than people living in big cities like those living in Amman and Zarqa. 


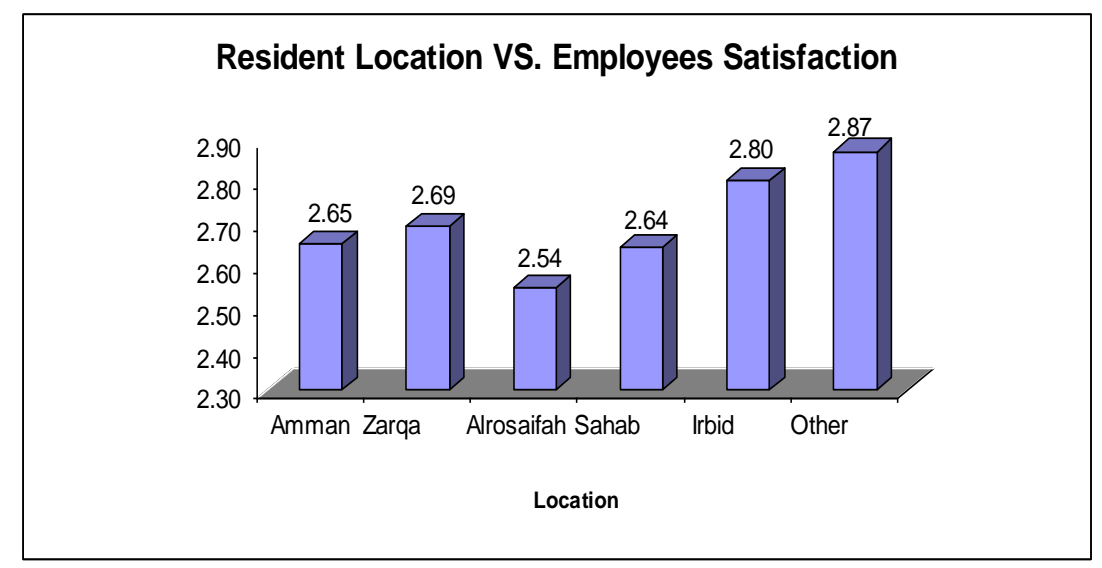

Figure 7: The effect of resident location on workers satisfaction

\section{CONCLUSIONS AND RECOMMENDATIONS}

Turnover rate in the third developing countries and in Jordan as an example is high. This is related mainly to low salaries, working and environmental conditions, services provided to employee by the employer, employee unsatisfaction and worker psychological state with surrounding environment. Employers and governments should put some rules and resolutions to improve the employee conditions and salaries in order to reduce the turnover that the developing countries are suffering from.

It is clearly noted from the study and its analysis, that the turnover inside the industrial zone is less than from the outside. This is due to better condition and stability inside these industrial zones. Therefore, it is recommended to increase the number of the industrial zones in such developing countries.

The dispersion measures for Worker Psychological State and Relationships with Surrounding Environment and Services Provided for Employee by the Employer, is high, which means there are no rules, regulations or set of laws available to control such matters.

In Jordan, as an example of Middle Eastern countries, the industrial sector has a problem of workers' turnover that is related mainly to working conditions and environment and salary. So, those working conditions should be improved to reduce the turnover problem. Salary is a main issue especially in big cities like the capital Amman.

\section{REFERENCES}

1. Lane, J., D. Stevens and S. Burgess, 1996, Worker and job flows, Economics Letters 51, 109-113.

2. Hassink, W., 1996, An empirical note on job turnover and internal mobility of workers, Economics Letters 51, 339-344. 


\section{Mll Macrothink}

3. Lee, T. and S. Maurer, 1997, The retention of knowledge workers with the unfolding model of voluntary turnover, Human Resource Management Review 7, No. 3, 247-275.

4. Bartol, K. and D. Martin, 1998, Applicant referent information at hiring interview and subsequent turnover among part-time workers, Journal of Vocational Behavior 53, 334-352.

5. Lucifora, C., 1998, The impact of unions on labour turnover in Italy: evidence from establishment level data, International Journal of Industrial Organization 16, 353-376.

6. Lehmann, H. and J. Wadsworth, 2000, Tenures that shook the world: worker turnover in Russia, Poland, and Britain, Journal of Comparative Economics 28, 639-664.

7. Strand, J., 2000, Wage bargaining and turnover costs with heterogeneous labor and asymmetric information, Labour Economics 7. 95-116.

8. Lambert, E., N. Hogan and S. Barton, 2001, The impact of job satisfaction on turnover intent: a test of a structural measurement model using a national sample of workers, The Social Science Journal 38, 233-250.

9. Gautier, P., G. Berg; J. Ours and G. Ridder, 2002, Worker turnover at the firm level and crowding out of lower educated workers, European Economic Review 46, 523-538.

10. Haltiwanger, J. and M. Vodopivec, 2002, Gross worker and job flows in a transition economy: an analysis of Estonia, Labour Economics 9, 601-630.

11. Maertz, C., M. Stevens and M. Campion, 2003, A turnover model for the Mexican maquiladoras, Journal of Vocational Behavior 63, 111-135.

12. Alfaro, J. and J. Tribo, 2003, Operations manager turnover and inventory fluctuations, Int. J. Production Economics 81-82, 51-58.

13. Bauer, T. and S. Bender, 2004, Technological change, organizational change, and job turnover, Labour Economics 11, 265- 291.

14. Munasinghe, L. and K. Sigman, 2004, A hobo syndrome? Mobility, wages, and job turnover, Labour Economics 11, 191- 218.

15. Tsou, M. and J. Liu, 2005, Wage dispersion and employment turnover in Taiwan, Economics Letters 88, 408-414.

16. Dale-Olsen, H., 2006, Wages, fringe benefits and worker turnover, Labour Economics $13,87-105$.

17. Liu, D., 2006, The entry and exit of workers in Taiwan, Economics Letters 92, 330-332.

18. Munasinghe, L., 2006, Expectations matter: Job prospects and turnover dynamics, Labour Economics 13, 589-609.

19. Morrison, P., K. Papps and J. Poot, 2006, Wages, employment, labour turnover and the accessibility of local labour markets, Labour Economics 13, 639-663.

20. Sousa-Poza, A. and A. Sousa-Poza, 2007, The effect of job satisfaction on labor turnover by gender: An analysis for Switzerland, The Journal of Socio-Economics 36, 895-913.

21. Senter, J. and J. Martin, 2007, Factors affecting the turnover of different groups of part-time workers, Journal of Vocational Behavior 71, 45-68. 
22. Wheeler, C., 2008, Worker turnover, industry localization, and producer size, Journal of Economic Behavior \& Organization 66, 322-334.

23. Chen, H., C. Chu, Y. Wang and L. Lin, 2008, Turnover factors revisited: A longitudinal study of Taiwan-based staff nurses, International Journal of Nursing Studies 45, 277-285.

24. McKnight, D., B. Phillips and B Hardgrave, 2009, Which reduces IT turnover intention the most: Workplace characteristics or job characteristics?, Information \& Management 46, 167-174.

APPENDIX

APPENDIX: THE QUESTIONAIRE USED IN THIS TURNOVER STUDY

A Questionnaire about Workers Turn Over in Jordanian Industrial Sector

Criterion A: Salary

\begin{tabular}{|c|l|}
\hline Question No. & \multicolumn{1}{c|}{ Question } \\
\hline $\mathbf{1}$ & Salary is sufficient for basic needs \\
\hline $\mathbf{2}$ & You will not get higher salary if you work in another place \\
\hline 3 & You get money for working overtime \\
\hline $\mathbf{4}$ & Annual bonus covers prices increase \\
\hline $\mathbf{5}$ & $\begin{array}{l}\text { You will not get higher salary if you work in another company of } \\
\text { same production }\end{array}$ \\
\hline 6 & Working overtime is financially good idea \\
\hline 7 & $\begin{array}{l}\text { Improving working conditions makes you stay in the job even with } \\
\text { same salary }\end{array}$ \\
\hline
\end{tabular}

Criterion B: Working Conditions and Environment

\begin{tabular}{|c|l|}
\hline Question No. & \multicolumn{1}{|c|}{ Question } \\
\hline $\mathbf{1}$ & $\begin{array}{l}\text { Chairs, Tables and other tools and equipments in the factory are } \\
\text { healthy and comfortable for your body }\end{array}$ \\
\hline $\mathbf{2}$ & $\begin{array}{l}\text { Lightening in the factory is good enough to perform your job } \\
\text { without hurting your eyes. }\end{array}$ \\
\hline $\mathbf{3}$ & Air is not polluted in the factory \\
\hline $\mathbf{4}$ & $\begin{array}{l}\text { Noise level in the factory is proper to successfully complete the } \\
\text { job. }\end{array}$ \\
\hline $\mathbf{5}$ & $\begin{array}{l}\text { General safety stuff and tools are available for you during } \\
\text { working. }\end{array}$ \\
\hline $\mathbf{6}$ & $\begin{array}{l}\text { You must use general safety stuff and tools during performing the } \\
\text { job }\end{array}$ \\
\hline
\end{tabular}




\begin{tabular}{|c|l|}
\hline 7 & $\begin{array}{l}\text { Seminars must be held or brochure must be distributed to realize } \\
\text { the importance of using the general safety stuff and tools. }\end{array}$ \\
\hline $\mathbf{8}$ & Number of daily working hours is convenient \\
\hline $\mathbf{1 0}$ & Break time length is enough \\
\hline 11 & $\begin{array}{l}\text { It is not convenient to split the break time into two breaks with } \\
\text { sufficient time between them }\end{array}$ \\
\hline 12 & You find proper place to spend your break time in. \\
\hline 13 & $\begin{array}{l}\text { There is great care for cleaning in the cafeteria, the rest rooms } \\
\text { and every where in the factory. }\end{array}$ \\
\hline 14 & There is special place for smoking \\
\hline 15 & Cafeteria services is satisfactory \\
\hline 16 & $\begin{array}{l}\text { Sufficient space is available for you to complete your job } \\
\text { successfully }\end{array}$ \\
\hline 17 & $\begin{array}{l}\text { You never been asked to do works which are not under your } \\
\text { responsibility }\end{array}$ \\
\hline 18 & Your job is very comfortable \\
\hline 19 & The work you do is not exceeding your body capabilities \\
\hline 20 & Training courses in your field area are usually conducted \\
\hline 21 & $\begin{array}{l}\text { Changing your shift does not affect your performance in doing the } \\
\text { job }\end{array}$ \\
\hline & \\
\hline &
\end{tabular}

Criterion C: Company or Factory Corporation with Employee: The management is cooperated and helpful in:

\begin{tabular}{|c|l|}
\hline Question No. & Question \\
\hline 1 & Completing your study \\
\hline 2 & Work accidents \\
\hline 3 & Health problems \\
\hline 4 & Resolving misunderstanding and problems between workers \\
\hline 5 & Family disasters (death, sickness, ...etc) \\
\hline 6 & Unreasonable warnings \\
\hline 7 & Considering your requests seriously \\
\hline $\mathbf{8}$ & Taking breaks and days off \\
\hline $\mathbf{1 0}$ & Living far away from work place \\
\hline 11 & Problems in transportation \\
\hline & Difficulties in work that happens sometimes \\
\hline
\end{tabular}

Criterion D: Worker Psychological State and Relationships with Surrounding Environment: 


\begin{tabular}{|c|l|}
\hline Question No. & \multicolumn{1}{c|}{ Question } \\
\hline $\mathbf{1}$ & You feel psychologically comfortable during performing your job \\
\hline 2 & You feel psychologically comfortable because of managers and workers \\
\hline $\mathbf{3}$ & There must be a psychologist exist \\
\hline $\mathbf{4}$ & Relationships between workers are good \\
\hline $\mathbf{5}$ & No difficulties are there to contact top management people \\
\hline $\mathbf{6}$ & You feel team work spirit, all working as a team \\
\hline $\mathbf{7}$ & Fair competition between workers \\
\hline $\mathbf{9}$ & You are not treated moody by your supervisor \\
\hline $\mathbf{1 0}$ & All workers are treated equally with no discrimination \\
\hline & You like your job because it is interesting \\
\hline
\end{tabular}

Criterion E: Services Provided for Employee by the Employer

\begin{tabular}{|c|c|}
\hline Question No. & Question \\
\hline 1 & $\begin{array}{l}\text { There is welcome meting for new workers, as well as around in the } \\
\text { factory to describe the job nature and makes you meet and know } \\
\text { your coworkers and supervisors. }\end{array}$ \\
\hline 2 & Uniform and winter coat is provided \\
\hline 3 & A doctor exists in the factory all the time. \\
\hline 4 & Comprehensive health insurance \\
\hline 5 & Transportation from you living place to the factory is provided \\
\hline 6 & General safety and cleaning stuff is provided \\
\hline 7 & $\begin{array}{l}\text { Transportation provided by the company is comfortable; buses are } \\
\text { air conditioned in the summer and warm in winter. }\end{array}$ \\
\hline 8 & Loans with easy and fair conditions \\
\hline 9 & Reasonable salary increase for getting married and having children \\
\hline 10 & Entertainment aspects are provided (journeys, parties...) \\
\hline 11 & Easy admission for sickness breaks without complications. \\
\hline 12 & $\begin{array}{l}\text { Periodic questionnaires to improve the factory and the employee } \\
\text { working conditions }\end{array}$ \\
\hline 13 & $\begin{array}{l}\text { Final meeting for you if you decide to retire or leave to know the } \\
\text { reasons. }\end{array}$ \\
\hline 14 & $\begin{array}{l}\text { The company pays you for working sufficient period of time for it } \\
\text { when you leave or retire. }\end{array}$ \\
\hline
\end{tabular}

